\title{
In vitro gas production from cassava peels supplemented with unconventional nitrogen sources and forages by small ruminants
}

\author{
Godfrey Adokiye Kalio
}

\author{
Department of Agriculture, Ignatius Ajuru University of Education, Ndele, P.M.B. 5046, Port Harcourt, Nigeria. \\ Email: ag.kalio@yahoo.com; Tel: +2348033000589.
}

\begin{abstract}
Copyright (@ 2019 Kalio. This article remains permanently open access under the terms of the Creative Commons Attribution License 4.0, which permits unrestricted use, distribution, and reproduction in any medium, provided the original work is properly cited.
\end{abstract}

Received 4th December, 2018; Accepted 15th January, 2019

\begin{abstract}
A study was conducted to ascertain the nutritional value of $\mathrm{N}$-source treated and forage supplemented cassava peels (CSP) using in vitro gas production technique. Cassava peels were treated and supplemented with materials rich in nitrogen: fertilizer grade urea $\left(T_{1}=C S P+U\right)$, broiler litter $\left(T_{2}=C S P+B L\right)$, cassava forage $\left(T_{3}=C S P+\right.$ $\mathrm{CSF})$ and sweet potato forage $\left(\mathrm{T}_{4}=\mathrm{CSP}+\mathrm{SPF}\right)$. Results revealed that, CSP supplemented with CSF $\left(\mathrm{T}_{3}\right)$ and SPF $\left(\mathrm{T}_{4}\right)$ recorded better gas production (31.90 and $32.20 \mathrm{~mL} / 200 \mathrm{mg} \mathrm{DM}$ ), metabolizable energy (ME) (7.54 and $7.67 \mathrm{MJ} / \mathrm{kg} \mathrm{DM}$ ), and organic matter digestibility (OMD) (52.02 and 52.80\%), respectively. Similarly, the estimated short chain fatty acids (SCFA) revealed higher values of 0.70 and $0.71 \mu \mathrm{M}$, respectively, for cassava and sweet potato forage supplementation compared to those fed urea and broiler litter-treated cassava peels. The superiority exhibited by the forage supplemented cassava peel diets for meeting the ME levels, SCFAs and OMD reveals that, cassava peels supplemented with either cassava leaves or sweet potato forage are valuable sources of nutrients for sheep and goats in terms of meeting their energy requirements for maintenance and part or all their milk production needs depending on the level of productivity.
\end{abstract}

Keywords: Cassava peels, forage, goats, nutritional value, sheep, supplementation, sweet potato.

\section{INTRODUCTION}

Rapid growth in human and livestock population in SubSaharan Africa is creating unprecedented increases in food and feed demands. Such population pressure on a fixed land base is, likely, to promote stern competition for resources and, progressively, force agriculture in the direction of intensification (Smith et al., 1997). For such intensification to work, effectively, under smallholder livestock farming, research is required to develop alternatives that will promote better resource use, less environmental impacts, increase farm income, and promote farmers' livelihoods in Nigeria and other parts of Sub-Saharan Africa.

The in vitro method is a laboratory technique for feed evaluation, which has numerous advantages over the in vivo method since it utilizes small amounts of test feeds suitable for screening large samples of feed (Njidda et al., 2010). Other benefits of the in vitro technique are that, it is less expensive, less time consuming, accurate, allows more precise maintenance of incubation conditions and simulates the rumen fermentation process making it useful for evaluating the potentials of feedstuffs to supply nutrients to ruminants (Akinfemi et al., 2009). It helps to simulate the digestive processes generated by microbial activities and to understand feed fermentation and degradability as a function of nutritional quality and nutrient availability for the rumen bacteria (Murillo et al., 2011). It is less animal dependent; more appropriate for characterizing soluble and small particulate feeds and can be automated thus reducing the labour input (Adesogan, 2002). It has been widely used to estimate the nutritive quality of cereal straws (Valizadeh et al., 2010). Similarly, it has also been successfully used to evaluate compounded feeds as well as for determining the effects of anti-nutritive factors in African browse plants on rumen 
fermentation and for predicting feed intake, digestibility, microbial nitrogen supply and animal performance (Getachew et al., 2004a; Akinfemi et al., 2009; Boga, 2014).

A survey conducted in cross River State of Nigeria indicated that, crop by-products predominantly cassava peels are available in large quantities in the rural communities that may serve as valuable feed resources for small ruminants (Kalio et al., 2013). Consequently, there is also the need to upgrade the feeding value of these crop by-products by interfering with the protective effect of lignin on the availability of the substrate to the rumen bacteria or to hydrolytic enzymes (Preston and Leng, 1986). This process can be enhanced by using simple inexpensive processes such as treatment with nonprotein nitrogenous (NPN) sources like urea and broiler litter or supplementation with nitrogenous forages such as cassava and sweet potato leaves that could increase the utilization of these crop by-products through digestibility trials (Kalio et al., 2014). However, there is little information on in vitro ruminal gas production by small ruminants fed unconventional nitrogen treated or forage supplemented cassava peels. Therefore, the aim of this study was to evaluate in vitro gas production from cassava peels supplemented with unconventional nitrogen sources and forages by small ruminants.

\section{MATERIALS AND METHODS}

\section{Experimental site and feed preparation}

The study was conducted at the Ruminant Nutrition Laboratory of the University of Ibadan, Ibadan, Nigeria while, the feed samples were collected from the Teaching and Research Farm of the University of Calabar, Calabar, Nigeria. Dried cassava peels (CSP) were treated and supplemented with different unconventional nitrogen sources: Urea $(\mathrm{U})$, broilers litter $(\mathrm{BL})$ and forages (cassava forage- CSF and sweet potato forage - SPF) to give four treatments namely:

1. $\mathrm{T}_{1}=$ cassava peels + urea $(\mathrm{CSP}+\mathrm{U})$;

2. $\mathrm{T}_{2}=$ cassava peels + broiler litter $(\mathrm{CSP}+\mathrm{BL})$;

3. $\mathrm{T}_{3}=$ cassava peels + cassava forage $(\mathrm{CSP}+\mathrm{CSF})$, and

4. $\mathrm{T}_{4}=$ cassava peels + sweet potato forage $(\mathrm{CSP}+\mathrm{SPF})$.

\section{Experimental animal management and feeding}

Prior to the commencement of the in vitro gas production studies, a ram weighing $11 \mathrm{~kg}$ was kept for an adaptation period of 5 days in a metabolic cage measuring $3 \mathrm{~m} \times 2 \mathrm{~m}$ $\mathrm{x} 4 \mathrm{~m}$ and used for rumen fluid collection. Feed, water and mineral-salt licks were provided ad libitum. Feed was provided, daily, at the rate of $5 \%$ of the body weight of the ram. The feed fed to the ram comprised a basal diet of $60 \%$
Panicum maximum and $40 \%$ concentrate $(40 \%$ corn, $10 \%$ wheat offal, $10 \%$ palm kernel cake, $20 \%$ groundnut cake, $5 \%$ soya bean meal, $10 \%$ dried brewers grain, $10 \%$ common salt, $3.75 \%$ oyster shell, and $0.25 \%$ fish meal).

\section{In vitro gas production}

Rumen fluid was obtained from the ram through a suction tube before the morning feed and put into a thermo flask that had been pre-warmed to a temperature of $39^{\circ} \mathrm{C}$ (Babayemi et al., 2009). The incubation was conducted following standard procedures using $120 \mathrm{ml}$ calibrated syringes in three batches maintained at a temperature of 39 to $40^{\circ} \mathrm{C}$ (Menke and Steingass, 1988). About $200 \mathrm{mg}$ of the feed samples were then weighed into the syringe and added to $30 \mathrm{~mL}$ of inoculums containing cheese cloth strained rumen liquor and buffer (comprising $9.8 \mathrm{~g}$ $\mathrm{NaHCO}_{3}+2.77 \mathrm{~g}, \mathrm{Na}_{2} \mathrm{HPO}_{4}+0.57 \mathrm{~g} \mathrm{KCl}+0.47 \mathrm{~g} \mathrm{NaCl}+$ $0.12 \mathrm{~g} \mathrm{MgSO}_{4} .7 \mathrm{H}_{2} \mathrm{O}+16 \mathrm{~g} \mathrm{CaCl}_{2}$. $2 \mathrm{H}_{2} \mathrm{O}$ ) per litre.

Rumen liquor and buffer were mixed together in the ratio $1: 4(\mathrm{v} / \mathrm{v})$ under continuous flushing with $\mathrm{CO}_{2}$. Using $50 \mathrm{~mL}$ calibrated plastic syringe, $30 \mathrm{~mL}$ of inoculums was dispensed into the substrate through the silicon tube. The plunger was pushed upward by pushing the inoculums to the tip of the syringe to completely eliminate air. The silicon tube in the syringe was then tightened by a metal clip so as to prevent escape of gas. The volume of gas produced was measured at 3 hourly bases $(3,6,9,12,15,18,21$, $24,27,30,33,36,39,42,45$, and $48 \mathrm{~h}$ ). The volume of gas produced was then read by measuring the space formed between the top of the piston and the liquid in the syringe. At the termination of the 24, 36 and $48 \mathrm{~h}$ incubation periods, $4 \mathrm{~mL}$ of $\mathrm{NaOH}(10 \mathrm{M})$ was introduced to each of the syringes containing the samples for methane $\left(\mathrm{CH}_{4}\right)$ gas determination. The gas volume was determined by difference, by subtracting the average gas production values of the blank from the individual feed samples. The volume of $\mathrm{CO}_{2}$ was determined by subtracting the $\mathrm{CH}_{4}$ gas production from the gas volume.

\section{Chemical analysis}

Chemical analysis of the feed samples for this study were similar to the procedures and results obtained by Kalio et al. (2014) in their study while investigating the performance of West African Dwarf (WAD) goats fed Ntreated source and forage supplemented cassava peels in humid Cross River State, Nigeria.

\section{Metabolizable energy, organic matter digestibility and short chain fatty acid estimation}

Metabolizable energy was estimated as (ME, MJ/kg DM) = $2.20+0.136^{*} \mathrm{Gv}+0.057^{*} \mathrm{CP}+0.0029^{*} \mathrm{CF}$. Similarly, 
organic matter digestibility (OMD) was estimated as $\mathrm{OMD} \%=14.88+0.889^{*} \mathrm{Gv}+0.45^{*} \mathrm{CP}+0.0651^{*} \mathrm{XA}$, while short chain fatty acid (SCFA) was estimated as SCFA = $0.0239^{*} \mathrm{Gv}$ - 0.0601; where $\mathrm{Gv}=$ net gas production $(\mathrm{mL} / 200 \mathrm{mg} \mathrm{DM}), \mathrm{CP}=$ crude protein, $\mathrm{CF}=$ crude fibre, and $X A=$ ash contents, respectively, of the incubated samples (Menke and Steingass, 1988).

\section{Statistical analysis}

Data obtained from the in vitro studies were analysed using analysis of variance (ANOVA) as described by SAS (1999). Where significant differences were detected, means were separated using the New Duncan's Multiple Range Test (Steel and Torrie, 1980).

\section{RESULTS AND DISCUSSION}

\section{Proximate composition of experimental diets}

The proximate composition of forage supplemented and $\mathrm{N}$-treated cassava peels for the study is similar to those reported by Kalio et al. (2014) in their study while investigating the performance of West African Dwarf (WAD) goats fed N-treated source and forage supplemented cassava peels in humid Cross River State, Nigeria.

\section{Estimation of the nutritional value by in vitro gas production techniques}

The results of the in vitro gas production, estimated metabolizable energy (ME), short chain fatty acid (SCFA) and organic matter digestibility (OMD) of urea and broiler litter treated and forage supplemented cassava peels via the in vitro gas production technique are presented in Table 1. There were significant $(p<0.05)$ variations in the gas volume (Gv), metabolizable energy (ME), short chain fatty acids (SCFAs) and organic matter digestibility (OMD) among the cassava peels treated with urea $\left(T_{1}: C S P+U\right)$ and broiler litter $\left(\mathrm{T}_{2}: \mathrm{CSP}+\mathrm{BL}\right)$ and those cassava peels supplemented with cassava forage ( $\left.\mathrm{T}_{3}: \mathrm{CSP}+\mathrm{CSF}\right)$ and sweet potato forage ( $\mathrm{T}_{4}$ : CSP $\left.+\mathrm{SPF}\right)$.

The gas volume (Gv) produced in order of decreasing volumes for the different feedstuffs after 48 hours of incubation were $32.20,31.90,21.17$ and $18.17 \mathrm{~mL} / 200 \mathrm{mg}$ $\mathrm{DM}$ for $\mathrm{T}_{4}(\mathrm{CSP}+\mathrm{SPF}), \mathrm{T}_{3}(\mathrm{CSP}+\mathrm{CSF}), \mathrm{T}_{2}(\mathrm{CSP}+\mathrm{BL})$ and $T_{1}(C S P+U)$, respectively. However, the gas volumes produced by $\mathrm{T}_{4}(\mathrm{CSP}+\mathrm{SPF})$ and $\mathrm{T}_{3}(\mathrm{CSP}+\mathrm{CSF})$ were not significantly $(p>0.05)$ different. This study revealed that, the cassava peels supplemented with the forages from cassava and sweet potato plants recorded the highest gas volumes after 48 hours of incubation. This may be attributed to the fact that, the forages have fermentable and readily degradable cell wall fractions, which would increase the substrates available to cellulolytic microbes with a consequent increase in the population of these microorganisms (Van Soest, 1982). Similarly, the presence of these microbes influences the extent and rate of substrate degradation, which is related to the gas volumes produced (Blümmel et al., 1997). The gas produced by the different feedstuffs increased with increasing hours of incubation, but gradually stabilized with no additional gas volumes produced between 42 and 48 hours of incubation. The gas production trends of the different feedstuffs are presented in Figure 1.

The metabolizable energy (ME) of the different feedstuffs in order of decreasing values after 48 hours of incubation were 7.67, 7.54, 6.56 and $6.42 \mathrm{MJ} / \mathrm{kg} \mathrm{DM}$ for $\mathrm{T}_{4}$ $(\mathrm{CSP}+\mathrm{SPF}), \mathrm{T}_{3}(\mathrm{CSP}+\mathrm{CSF}), \mathrm{T}_{2}(\mathrm{CSP}+\mathrm{BL})$ and $\mathrm{T}_{1}(\mathrm{CSP}$ $+U)$, respectively. This is slightly higher than the range of ME values (4.46 to $7.42 \mathrm{MJ} / \mathrm{kg} \mathrm{DM}$ ) reported by Songsak et al. (2007) for some energy feeds in Thailand. However, the metabolizable energy of the feedstuffs: $\mathrm{T}_{4}(\mathrm{CSP}+\mathrm{SPF})$ and $T_{3}(C S P+C S F)$ were not significantly $(p>0.05)$ different and were higher. The results revealed that, the cassava peels supplemented with cassava forage $\left(T_{3}\right.$ : $\mathrm{CSP}+\mathrm{CSF})$ and sweet potato forage $\left(\mathrm{T}_{4}: \mathrm{CSP}+\mathrm{SPF}\right)$ possess a higher ME values than the ME values for $T_{1}$ $(\mathrm{CSP}+\mathrm{U})$ and $\mathrm{T}_{2}(\mathrm{CSP}+\mathrm{BL})$. However, it is important to note that urea has no energy value of its own (Maynard et al., 1984). Consequently, the energy value recorded in $T_{1}$ $(C S P+U)$ is simply due to the associative effect of cassava peels (CSP) with urea (U) in the feed mixture. This is in agreement with the findings of Getachew et al. (2004b), who explained that, feeding straw alone to a ruminant reduces its digestibility, but by adding nitrogen in the form of urea or protein, the digestibility of the straw will be increased and in turn, the energy derived from straw organic matter in the diet will also be increased. The ME values recorded in this study revealed that, the ME of the different diets were within the recommended $M E$ values for an average diet (6 to $13 \mathrm{MJ} / \mathrm{kg} \mathrm{DM}$ ) (Steele, 2006) hence, can fulfil the energy requirements for the West African Dwarf (WAD) small ruminants (sheep and goats). Furthermore, the derivation of these ME values for these feeds could be valuable for purposes of ration formulation and to set the economic value of the feeds for trading (Njidda et al., 2010).

The short chain fatty acids (SCFAs) or volatile fatty acids (VFAs) of the different diets in order of decreasing values after 48 hours of incubation were $0.71,0.70,0.45$ and 0.37 $\mu \mathrm{M}$ for $\mathrm{T}_{4}(\mathrm{CSP}+\mathrm{SPF}), \mathrm{T}_{3}(\mathrm{CSP}+\mathrm{CSF}), \mathrm{T}_{2}(\mathrm{CSP}+\mathrm{BL})$ and $T_{1}(C S P+U)$, respectively. The SCFA value of the $T_{4}$ $(\mathrm{CSP}+\mathrm{SPF})$ treatment was higher although, they were not significantly $(p>0.05)$ different from the $\mathrm{T}_{3}(\mathrm{CSP}+\mathrm{CSF})$ treatment group. The $\mathrm{T}_{4}(\mathrm{CSP}+\mathrm{SPF})$ and $\mathrm{T}_{3}(\mathrm{CSP}+\mathrm{CSF})$ treatment groups recorded the highest values of SCFAs. The SCFAs or VFAs such as acetic, propionic, butyric, isobutyric, valeric, isovaleric, 2-methylbutyric, hexanoic and heptanoic acids have been reported as major sources 
Table 1. In vitro gas production, estimated metabolizable energy (ME), short chain fatty acid (SCFA) and organic matter digestibility (OMD) of treated and forage supplemented cassava peels.

\begin{tabular}{|c|c|c|c|c|c|c|}
\hline \multirow[b]{2}{*}{ Parameters } & \multicolumn{4}{|c|}{ Feed materials } & \multirow[b]{2}{*}{ Mean } & \multirow[b]{2}{*}{ \pm SEM } \\
\hline & $\begin{array}{c}\mathrm{T}_{1} \\
(\mathrm{CSP}+\mathrm{U})\end{array}$ & $\begin{array}{c}\mathrm{T}_{2} \\
(\mathrm{CSP}+\mathrm{BL})\end{array}$ & $\begin{array}{c}\mathrm{T}_{3} \\
(\mathrm{CSP}+\mathrm{CSF})\end{array}$ & $\begin{array}{c}\mathrm{T}_{4} \\
(\mathrm{CSP}+\mathrm{SPF})\end{array}$ & & \\
\hline Gas volume, Gv (mL/200 mg DM) & $18.17^{\mathrm{c}}$ & $21.17^{\mathrm{b}}$ & $31.90^{\mathrm{a}}$ & $32.20^{a}$ & 25.86 & 5.97 \\
\hline Metabolizable energy, ME (MJ/kg DM) & $6.42^{b}$ & $6.56^{\mathrm{b}}$ & $7.54^{\mathrm{a}}$ & $7.67^{\mathrm{a}}$ & 7.05 & 0.31 \\
\hline Short chain fatty acids, SCFA $(\mu \mathrm{M})$ & $0.37^{c}$ & $0.45^{b}$ & $0.70^{\mathrm{a}}$ & $0.71^{\mathrm{a}}$ & 0.56 & 0.05 \\
\hline Organic matter digestibility, OMD (\%) & $45.59^{b}$ & $46.21^{b}$ & $52.07^{\mathrm{a}}$ & $52.80^{\mathrm{a}}$ & 49.17 & 1.97 \\
\hline
\end{tabular}

a,b,c Meansbearing different superscripts along the same row are significantly different $(P<0.05)$. Metabolizable energy, ME $(\mathrm{MJ} / \mathrm{kgDM})=2.20+$ $0.136^{*} \mathrm{Gv}+0.057^{\star} \mathrm{CP}+0.0029^{\star} \mathrm{CF}$. Organic matter digestibility, OMD $(\%)=14.88+0.889^{\star} \mathrm{Gv}+0.45^{\star} \mathrm{CP}+0.0651^{\star} \mathrm{XA}$. Short chain fatty acids, $\operatorname{SCFA}(\mu \mathrm{M})=0.0239^{*} \mathrm{Gv}-0.0601$. Gv = Gas volume; $\mathrm{CP}=$ Crude protein; $\mathrm{CF}=$ Crude fibre; $\mathrm{XA}=\mathrm{Ash}$.

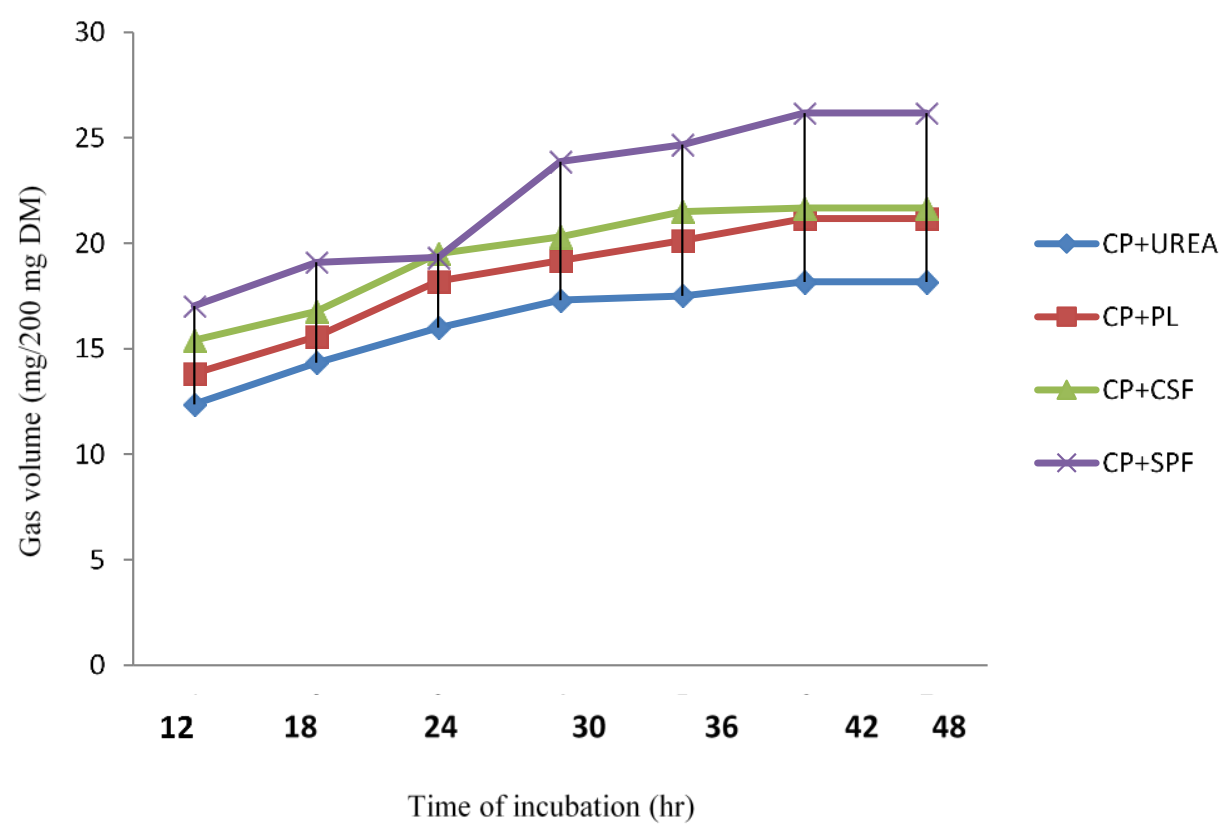

Figure 1. Gas production trends of treated and forage supplemented Cassava peels.

of energy as well as building blocks for milk synthesis (Bergman, 1990). Thus, the $\mathrm{T}_{4}(\mathrm{CSP}+\mathrm{SPF})$ and $\mathrm{T}_{3}$ (CSP + CSF) diets having recorded the highest value of SCFAs have better potentials to fulfil this role. Similarly, the results of the SCFAs for these diets have also been corroborated by the earlier ME values for these diets. This will, therefore, give a strong assurance for the provision of up to $80 \%$ of maintenance energy for WAD goats or any other ruminant when fed with this diet (Bergman, 1990).

The organic matter digestibility (OMD) of the different diets in order of decreasing values after 48 hours of incubation were $52.80,52.07,46.59$ and $45.59 \%$ for $\mathrm{T}_{4}$ $(\mathrm{CSP}+\mathrm{SPF}), \mathrm{T}_{3}(\mathrm{CSP}+\mathrm{CSF}), \mathrm{T}_{2}(\mathrm{CSP}+\mathrm{BL})$ and $\mathrm{T}_{1}(\mathrm{CSP}$ $+U)$, respectively. The OMD value of the $\mathrm{T}_{4}(\mathrm{CSP}+\mathrm{SPF})$ treatment was higher, although they were not significantly $(p>0.05)$ different from the $\mathrm{T}_{3}(\mathrm{CSP}+\mathrm{CSF})$ treatment group. The $\mathrm{T}_{4}(\mathrm{CSP}+\mathrm{SPF})$ and $\mathrm{T}_{3}(\mathrm{CSP}+\mathrm{CSF})$ treatment groups recorded the highest values of OMD. The OMD values recorded in this study were higher than those recorded by Alasa et al. (2010) in their studies while determining the chemical composition and in vitro gas production of Panicum maximum intercropped with two cultivars of Lablab purpureus, but lower than the OMD values reported by Adewumi and Ajayi (2010) in their studies conducted to determine the replacement value of full fat neem fruit for corn bran using in vitro gas production techniques. Consequently, this study revealed that the cassava peels supplemented with the forages from cassava $\left(T_{3}\right)$ and sweet potato $\left(T_{4}\right)$ plants recorded the highest OMD after 48 hours of incubation. This may be attributed to the fact that, the forages have fermentable nitrogen and readily degradable cell wall fractions which would increase the substrates available to cellulolytic microbes with a consequent increase in digestibility (Van 
Soest, 1982; Adebowale, 1994). In addition, the estimated higher and better OMD values recorded in the present study corroborate the results of the dry matter digestibility (DMD) values earlier reported in the in vivo studies by Kalio et al. (2014) for the various treatment groups. The trend of the results revealed that better OMD and DMD values were recorded for the in vitro and in vivo digestibility trials, respectively, for $\mathrm{T}_{4}(\mathrm{CSP}+\mathrm{SPF})$ and $\mathrm{T}_{3}(\mathrm{CSP}+$ $\mathrm{CSF})$ treatment groups compared to those of $\mathrm{T}_{1}(\mathrm{CSP}+\mathrm{U})$ and $\mathrm{T}_{2}(\mathrm{CSP}+\mathrm{BL})$ in the two trials. This supports the reports of Akinfemi et al. (2009) and Pashaei et al. (2010) who gave a positive relationship between results of in vivo and in vitro digestibility studies and further explained that, efficient laboratory methods should be reproducible and should correlate well with actually measured in vivo parameters. This is important because it can provide enough information on the nutritive value of the feedstuffs as opposed to the results of chemical analysis alone (Sallam, 2005).

\section{Conclusion and recommendation}

This study revealed that the cassava peels (CSP) supplemented with the forages from cassava and sweet potato plants recorded the highest gas volumes after 48 hours of incubation. Furthermore, these diets possess higher metabolizable energy (ME) values. The ME values recorded in the study were within the recommended ME values (range: 6 to $13 \mathrm{MJ} / \mathrm{kg} / \mathrm{DM}$ ) for an average diet, which can meet the daily energy requirements for small ruminants. Similarly, the cassava and sweet potato forage supplemented CSP recorded higher values for short chain fatty acids (SCFAs) compared to the urea and broiler litters supplemented CSP. This implies that these diets may be potential sources of energy as well as a building block for milk synthesis. The results of SCFAs of these diets corroborate the earlier ME values for these diets and can give a strong assurance for the provision of up to $80 \%$ of maintenance energy for sheep and goats. Also, the organic matter digestibility (OMD) values recorded for the cassava and sweet potato forage supplemented CSP suggest that they were better utilized by sheep and goats and therefore recommended for utilization in small ruminant animal feeding regimen.

\section{CONFLICT OF INTEREST}

The authors declare that they have no conflict of interest.

\section{REFERENCES}

Adebowale, E. A. (1994). Maize residues as ruminant feed resources in Nigeria. WAR/RMZ (73), 24-30. Available at http://www.fao.org/docrep/U8750T/u8750T0d.htm.

Adesogan, A. T. (2002). What are feeds worth? A critical evaluation of selected nutritive value methods. In: Proceedings of the 13th Annual Florida Ruminant Nutrition Symposium, Pp. 33-47.

Adewumi, M. K., \& Ajayi, D. A. (2010). Replacement value of full fat neem fruit for corn bran in the diet of West African Dwarf (WAD) Sheep. In: Babayemi, O. J., Abu, O. A., \& Ewuola, E. O. (Eds). Fast-tracking Animal Agriculture in a challenged economy. Proceedings of the $35^{\text {th }}$ Annual Conference of the Nigerian Society for Animal Production (NSAP), $14^{\text {th }}-17^{\text {th }}$ March, University of Ibadan, Ibadan, Nigeria. (pp 591-593).

Akinfemi, A., Adu, O. A., \& Aya, V. E. (2009). Use of in vitro gas production technique to evaluate some Nigerian feedstuffs. American-Eurasian Journal of Scientific Research, 4(4), 240245.

Alasa, M. C., Akinsola, S. O., \& Babayemi, O. J. (2010). Chemical composition and in vitro gas production of Panicum maximum intercropped with two cultivars of Lalab purpureus. In: Babayemi, O.J., Abu, O. A., \& Ewuola, E. O. (Eds). Fasttracking Animal Agriculture in a challenged economy. Proceedings of the $35^{\text {th }}$ Annual Conference of the Nigerian Society for Animal Production (NSAP), 14 ${ }^{\text {th }}-17^{\text {th }}$ March, University of Ibadan, Ibadan, Nigeria. (pp. 587-590).

Babayemi, O. J., Otukoye, F. K., Femilade, F. O., \& Daodu, M. O. (2009). Assessment of the nutritive value of bovine liquor and urea treated corn-straw and corn-cobs as feed for the West African Dwarf sheep and goats. Nigerian Journal of Animal Production, 36(2), 313-324.

Bergman, E. N. (1990). Energy contributions of volatile fatty acids from the gastrointestinal tract in various species. Physiology Review, 70, 567-590.

Blümmel, M., Makkar, H. P. S., \& Becker, K. (1997). In vitro gas production: a technique revisited. Journal of Animal Physiology and Animal Nutrition, 77(1-5), 24-34.

Boga, M. (2014). Chemical Composition and in vitro gas production kinetics of some tree leaves obtained in the Mediterranean region of Turkey. Anadolu Journal of Agricultural Science, 29(2), 143-146.

Getachew, G., De Peters, E. J., \& Robinson, P. H. (2004a). In vitro gas production provides effective method for assessing ruminant feeds. California Agriculture. 58(1), 54-58.

Getachew, G., Robinson, P. H., DePeters, E. J., \& Taylor, S. J. (2004b). Relationships between chemical composition, dry matter degradation and in vitro gas production of several ruminant feeds. Animal Feed Science and Technology, 111(14), 57-71.

Kalio, G. A., Agwunobi, L. N., Ayuk, A. A., \& Eneji, C. A. (2013). Availability and estimation of crop by-product yields for small ruminant production in Cross River State, Nigeria. Nigerian Journal of Animal Production, 40(1), 117-122.

Kalio, G. A., Ayuk, A. A., \& Agwunobi, L. N. (2014). Performance of West African Dwarf (WAD) goats fed n-treated source and forage supplemented cassava peels in humid Cross River State, Nigeria. American Journal of Experimental Agriculture, 4(6), 629-638.

Maynard, L. A., Loosli, J. K., Hitz, H., \& Warner, R. G. (1984). Animal Nutrition, 7th Edition, Tata McGraw Hill Publishing Company Ltd. (602p).

Menke, K. H., \& Steingass, H. (1988). Estimation of the energetic feed value from chemical analysis and in vitro gas production using rumen fluid. Animal Research and Development, 28, 755.

Murillo, M., Herrera, E., Reyes, O., Gurrol, J. N., \& Gutierrez, E. (2011). Use in vitro gas production technique for assessment of nutritional quality of diets by range steers. African Journal of 
Agricultural Research. 6(11), 2522-2526.

Njidda, A. A., Ikhimioya, I., \& Babayemi, O. J. (2010). Variation of 24 hour in vitro gas production and estimated metabolizable energy values of ruminant feeds. Proceedings of the 33th Annual Conference of the Nigerian Society for Animal Production (NSAP), March 14-17, 2010, Ibadan, Oyo State, Nigeria. (pp. 597-600).

Pashaei, S., Razmazar, V. \& Mirshekar, R. (2010). Gas production: A proposed in vitro method to estimate the extent of digestion of feedstuff in the rumen. Journal of Biological Sciences, 10(6), 573-580.

Preston, T. R., \& Leng, R. A. (1986). Matching Livestock Systems to Available Feed Resources. ILCA, Addis Ababa, Ethiopia. (200p).

Sallam, S. M. A. (2005). Nutritive value assessment of alternative feed resources by gas production and rumen fermentation in vitro. Research Journal of Agriculture and Biological Sciences, 1(2), 200-209.

SAS (1999). SAS for Windows, Version 8. (Statistical Analysis Systems) Institute Inc.: Cary, NC).

Smith, J. W, Naazie, A., Larbi, A., Agyemang, K., \& Tarawali, S. (1997). Integrated crop-livestock systems in Sub-Saharan Africa: an option or an imperative. Outlook on Agriculture, 26(4), 237-246.
Songsak, C., Anut, C., \& Piyanate C. (2007). Chemical compositions and nutritional evaluation of energy feeds for ruminant using in vitro gas production technique. Pakistan Journal of Nutrition. 6(6), 607-612.

Steel, R. G. D., \& Torrie, J. H. (1980). Principles and Procedures of Statistics. Biometric Approach, 2nd Edition, McGraw Hill Co. Inc., New York, USA.

Steele, M. (2006). Goats. CTA-Macmillan Publishing Ltd., London and Basingstoke. (152p).

Valizadeh, R, Sobhanirad, S, \& Mojtahedi, M. (2010). Chemical composition, ruminal degradability and in vitro gas production of wheat straw inoculated by Pleurotus ostreatus mushrooms. Journal of Animal Veterinary Advances, 7(11), 1506-1510.

Van Soest, P. J. (1982). Nutritional Ecology of Ruminants. O \& B Books Inc., Carvallis Oregon U.S.A. (374p). 